\title{
TEKNOLOGI POLIKULTUR KEPITING BAKAU DAN IKAN BANDENG PADA KELOMPOK PEMBUDIDAYA IKAN PERPAT PERMAI KELURAHAN AIR JUKUNG, KECAMATAN BELINYU, KABUPATEN BANGKA
}

\author{
Eva Prasetiyono ${ }^{1}$, Denny Syaputra \\ Jurusan Budidaya Perairan, Fakultas Pertanian Perikanan dan Biologi, \\ Universitas Bangka Belitung \\ 1)email : evaintegral@gmail.com
}

\begin{abstract}
ABSTRAK
Kelompok Pembudidaya Ikan (pokdakan) di Kelurahan Air Jukung, Kecamatan Belinyu, Kabupaten Bangka merupakan Kelompok pembudidaya ikan yang bergerak

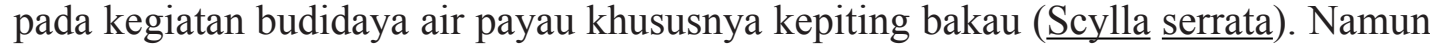
keberlanjutan kegiatan budidaya yang dilakukan masih terkandala oleh banyak hal salahsatunya adalah kurangnya efisiensi dalam pemanfaatan potensi sumberdaya yang dimiliki. Tambak yang dimiliki oleh para pembudidaya ikan masing belum terkelola dengan optimal. Tujuan kegiatan ini adalah memberikan aplikasi IPTEKS untuk mengefisiensikan potensi sumberdaya yang dimiliki oleh para pembudidaya ikan dengan teknologi pemeliharaan sistem polikultur antara kepiting bakau dengan ikan bandeng ( $\underline{\text { Chanos }}$ chanos). Target khusus dari kegiatan ini adalah Kapasitas produksi budidaya milik pokdakan semakin meningkat dan efisien dengan tearalikasinya teknologi polikultur. Metode kegiatan ini yaitu metode survey lapangan dengan menyisipkan teknologi polikultur dalam melakukan kegiatan budidaya. Hasil dari kegiatan ini yaitu tambak budidaya milik para pembudidaya ikan semakin optimal dan efesien dengan diversifikasi komoditi selain kepiting bakau yaitu ikan bandeng. Kepiting bakau mampu tumbuh dan hidup dengan optimal serta mencapai ukuran panen. Selain itu ikan bandeng yang dipelihara mampu hidup dan tumbuh dengan optimal dengan pertumbuhan yang sesuai dengan diharapkan.
\end{abstract}

Kata Kunci : Pembudidaya ikan, air payau, polikultur, kepiting bakau, ikan Bandeng.

\begin{abstract}
Fish Farmers Group (FFG) in Air Jukung Village, District of Belinyu, Regency of Bangka is a brackish water-fish farmers group concerned to produce mud crabs (Scylla serrata). However, there were many problems still engaged in the sustainability of mud crabs production in this area based on field survey methods. Not optimally land using for coastal ponds to culture the mud crabs is one of the problems. Coastal ponds owned by the fish farmers have not been optimally managed. The purpose of this activity is to provide an applied scientifically approach-technologies to culture the mud crabs and milkfish (Chanos chanos) more efficiently in the form of polyculture system. The specific target of this activity is to increase the production capacities of the FFGs. The results of this activity is an optimally used of coastal ponds by the diversification of commodities cultured i.e mud crabs and milkfish. The mud crabs grow optimally and reach the harvest size. In addition, the milkfish are also able to live and grow optimally as be expected.
\end{abstract}

Keywords : fish farmers, brackish water, polyculture, mud crabs, milkfish. 


\section{PENDAHULUAN}

Potensi perairan payau pada daerah bagian utara Pulau Bangka bagian sangat besar. Potensi ini akan memberikan hasil yang optimal jika dikelola dengan baik. Budidaya ikan merupakan salahsatu cara dalam mengelola potensi perairan payau. Apalagi nilai jual komoditi-komoditi ikan air payau lebih tinggi bila dibandingkan dengan ikan air tawar. Namun pengelolaan suatu perairan harus mengikuti kaidah kegiatan budidaya perairan, diantaranya yaitu efesien, menguntungkan dan berkelanjutan (Prasetiyono, 2013).

Budidaya ikan merupakan kegiatan produksi atau pemeliharaan ikan yang bertujuan untuk mendapatkan keuntungan (Effendi, 2004). Keuntungan optimal bisa didapatkan bila mampu meminimalisasi potensi sumberdaya yang dimiliki, baik sumberdaya modal, sumberdaya sarana dan prasarana maupun sumberdaya yang lainnya. Kapasitas produksi merupakan bagian sumberdaya modal. Kapasitas produksi akan lebih efisien dengan dukungan teknologi. Menurut Middlen dan Redding (1998), Kapasitas produksi dipengaruhi oleh sistem dan teknologi budidaya ikan.

Kepiting bakau (Scylla serrata) merupakan komoditi budidaya ikan air payau. Kegiatan budidaya kepiting bakau akan lebih optimal dalam menghasilkan keuntung jika kapasitas tambak yang digunakan untuk memeilhara mampu diefesienkan. Efesiensi dalam budidaya kepiting bakau dapat dilakukan dengan padat penebaran yang lebih tinggi atau dengan cara memelihara komoditi lain dalam satu tambak yang sama. Teknologi pemeliharan lebih dari satu komoditi dalam wadah pemeliharaan atau badan air yang sama disebut polikultur.

Ikan bandeng merupakan salahsatu komoditi yang dapat dipolikutur dengan kepiting bakau. Keunggulan Ikan Bandeng memiliki kelebihan sebagai komoditas budidaya. Kelebihannya yaitu dapat tumbuh dengan baik pada tambak tradisional, lebih tahan terhadap penyakit, panen dapat dilakukan dua kali dalam setahun, harga jualnya relatif stabil dann dapat diserap dipasar, bersifat herbivora sehingga dapat dibudidayakan dengan sistem polikultur (Muntalim dan Mas'ud, 2014). Kepiting bakau dengan karakteristik hidup didasar sedangkan ikan bandeng hidup didekat permukaan. Pemilihan komoditas untuk dipolikultur dengan kepiting bakau harus memiliki persyaratan. Persyaratanpersyaratan tersebut diantaranya yaitu komoditasnya bersifat plankton feeder, lincah sehingga tidak mudah ditangkap kepiting bakau (Rangka, 2007).Ikan bandeng merupakan ikan memenuhi persyaratan tersebut.

Pakan kepiting bakau berupa ikanikan rucah tidak semuanya termakan dan menghasilkan berupa partikel-partikel organik sisa yang dapat menyuburkan perairan dengan tumbuhnya mikroalga. Ikan bandeng yang dipelihara pada tambak dapat memanfaatkan mikroalga tersebut sebagai pakan (Ghufran, 2009). Polikultur tambak dengan diversifikasi komoditi kepiting bakau dan ikan bandeng mendukung efisiensi produksi tambak. Selain itu, polikultur juga mendukung kaidah budidaya yang berkelanjutan. Optimalisasi lahan tambak yang ada tanpa perluasan tambak atau pembukaan lahan baru akan meminimalisasi berubahnya eksosistem akibat beralihnya fungsi. Maka dengan teknologi polikultur, pembukaan tambak baru bisa dibatasi.

Budidaya kepiting bakau dengan memanfaatkan potensi air payau di Bangka salahsatunya dilakukan oleh Kelompok Pembudidaya Ikan (Pokdakan) Perpat Permai, Kel. Air Jukung, Kec. Belinyu, Kab.Bangka. Pokdakan ini berada di bagian utara Pulau Bangka. Selama ini kegiatan budidaya yang dilakukan belum efesien. Proses produksi masih terkendala oleh sarana dan prasarana yang belum memadai, bibit berkualitas yang susah didapatkan serta kapasitas tambak yang belum optimal. Padahal permintaan lokal terhadap kepiting bakau dan ikan bandeng sangat tinggi. Selain itu komoditi ini memiliki nilai ekspor 
yang sangat tinggi. Moosa et al. (1985) menyatakan bahwa kepiting bakau memiliki rasa daging dan telur yang gurih, kandungan proteinnya yaitu $65,7-82,6 \%$ dan kandungan lemak yaitu $0,9 \%$. Kandungan protein pada ikan bandeng yang dipelihara pada air payau yaitu 24,174\% dan kadar lemaknya 0,853\% (Hafiludin, 2015). Tingginya kandungan gizi menyebabkan kedua komoditi ini menyebabkan sangat digemari.

Penggunaan teknologi polikultur sebagai teknologi terapan mampu meningkatkan kuantitas dan kualitas hasil produksi tambak yang akan berdampak pada optimalnya kegiatan dan hasil budidaya ikan. Selain itu, Teknologi polikultur ini juga diharapkan mampu mendiversifikasi produk hasil budidaya sehingga perluasan pasar dan keuntungan yang didapatkan juga lebih optimal. Pada akhirnya kegiatan ini akan mampu meningkatkan kesejahteraan para pembudidaya dan menjadi pilot project bagi para pembudidaya yang lainnya.

\section{METODE PELAKSANAAN}

Kegiatan ini dilaksanakan pada bulan Juli 2017 sampai dengan November 2017. Tempat pelaksanaan di Tambak budidaya kepiting bakau yang digunakan yaitu Tambak milik kelompok pembudidaya ikan Perpat Permai.

Metode survey dan aplikasi langsung ke lapangan merupakan metode yang digunakan. Pendekatan dilakukan berdasarkan permasalahan-permasalahan yang dialami oleh para pembudidaya kepiting bakau yaitu melakukan kegiatan budidaya dengan menggunakan teknologi terapan.

Penerapan sistem dan teknologi budidaya kepiting bakau dilakukan dengan prosedur sebagai berikut:

\section{Penyiapan petak tambak}

Tambak yang digunakan yaitu tambak sengan dasar dan dinding tanah. Perbaikan tambak dilakukan dengan memperdalam dan mengangkat sedimen dasar untuk diletakan atau ditambah pada pematang. Disekeliling tambak dipasang waring hitam berlapis yang bertujuan agar kepiting bakau tidak keluar tambak dan menghindarkan predator (binatang) masuk kedalam tambak dan memangsa ikan.

2. Penyiapan karamba/kurungan untuk produksi

Pembuatan karamba dilakukan sebanyak dua komponen. Komponen yang pertama yaitu karamba/kurungan untuk pemeliharaan sebagian kepiting bakau. Komponen kedua yaitu keramba waring tancap yang digunakan sebagai wadah penampungan sementara ikan bandeng sebelum dilepas kedalam tambak.

3. Penyiapan alat pendukung dan penunjang untuk kegiatan budidaya

Alat-alat pendukung kegiatan budidaya yaitu alat-alat ukur kualitas air seperti : salinometer untuk mengukur salinitas, $\mathrm{pH}$ meter untuk mengukur $\mathrm{pH}$ air. Parameter kualitas air ini penting diketahui untuk melihat kesesuaian kualitas air dengan kehidupan komoditi yang dibudidayakan.

4. Penebaran Bibit Kepiting Bakau dan ikan bandeng ke Tambak

Kepiting bakau dan benih ikan bandeng ditebar di kolam. Bibit kepiting bakau yang dipilih yaitu yang berukuran seragam dengan berat 100-150 gram. Benih ikan bandeng yang ditebar yaitu benih ikan yang ukuran seragam dengan panjang 7-8 $\mathrm{cm}$ yang sudah mampu mengkonsumsi pelet.

5. Proses Kegiatan Budidaya

Proses Kegiatan Budidaya atau proses pemeliharaan kepiting bakau dan ikan bandeng dilakukan dengan memberikan pakan serta pengontrolan kualitas lingkungan. Pemeliharaan kepiting bakau dan ikan bandeng dilakukan dengan memberikan pakan sebanyak 2-3 kali sehari secara at satiation. Pakan kepiting bakau berupa ikan-ikan rucah sedangkan pakan ikan bandeng berupa pakan buatan pabrik komersil. Selama pemeliharaan dilakukan proses pengamatan terhadap kelangsungan 
hidup dan pertumbuhan kepiting bakau dan ikan bandeng.

6. Pemanenan dan Evaluasi Teknologi

Panen dilakukan ketika kepiting bakau dan ikan-ikan hasil budidaya sudah mencapai ukuran konsumsi ataun ukuran yang dikehendaki pasar. Ukuran ini dicapai dalam proses pemeliharaan selama 3-4 bulan. Pemanenan dilakukan tidak dengan menguras air namun menggunakan ancho, jaring atau mengangkat waring. Waktu pemanenan dilakukan pada pagi hari atau pada cuaca yang tidak terlalu panas. Setelah panen juga dilakukan proses evaluasi terhadap teknologi yang diterapkan pada kegiatan budidaya.

\section{HASIL DAN PEMBAHASAN}

\section{Gambaran Umum Lokasi}

Pokdakan Perpat Permai memiliki tambak yang berlokasi pada sebelah aliran anak sungai dekat daerah muara. Lokasi tambak berada pada titik koordinat 1³8'36.1' LS dan 105'45'51.9' BT. Tambak ini dikelilingi oleh hutan mangrove yang masih cukup baik. Lokasi tambak cukup dekat dengan kediaman para pembudidaya ikan yaitu sekitar 200 meter. Akses menuju lokasi cukup mudah dicapai.

Daerah di sekitar lokasi sering dimanfaatkan oleh masyarakat untuk menangkap kepiting bakau liar dari alam. Produktivitas tambak yang dekat dengan hutan mangrove sangat tinggi. Kedalam tambaknya yaitu 0,5 - 1,5 meter. Dasar tambak adalah tanah dengan karakteristik lumpur berpasir. Dasar tambak ini merupakan habitat yang disukai oleh kepiting bakau dan ikan bandeng. FAO (2011) menyatakan bahwa kepiting bakau lebih suka hidup di perairan yang relatif dangkal dengan dasar berlumpur. Rattanachote dan Dangwatanakul (1991) menyatakan bahwa karakteristik habitat dari kepiting bakau yaitu di daerah seperti estuaria, daerah hutan bakau dan pada daerah lepas pantai yang mempunyai subtrat dasar perairan berlumpur. Salinitas airnya lebih kurang 22 - 32 ppt.

Kondisi lingkungan perairan pada tambak milik Pokdakan Perpat Permat sangat baik. Selama ini, tambak ini sangat dipengaruhi oleh pasang surut air laut. Tambak akan memiliki volume air laut jika terjadi pasang dan sebaliknya jika air laut surut, maka ketersediaan air didalam tambak juga sedikit. Kondisi ini menyebabkan tambak tidak optimal digunakan untuk kegiatan budidaya. Selama ini tambak tidak berjalan dan berfungsi dengan baik. Kondisi tambak cukup terbengkalai. Hal ini dikarenakan modal produksi yang rendah, bibit yang sulit didapat dan pendampingan terhadap kegiatan produksi tidak ada. Selain itu, teknologi terapan yang mampu mengoptimalkan dan mengefisiensikan produksi tambak masih menjadi kendala yang cukup berarti. Padahal ketersediaan pasar terhadap komoditi air payau terutama kepiting bakau dan ikan bandeng cukup tinggi untuk daerah lokal.

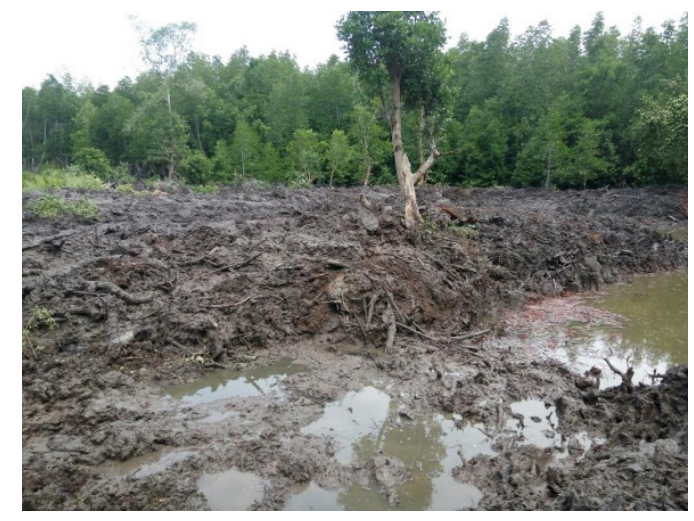

(a)

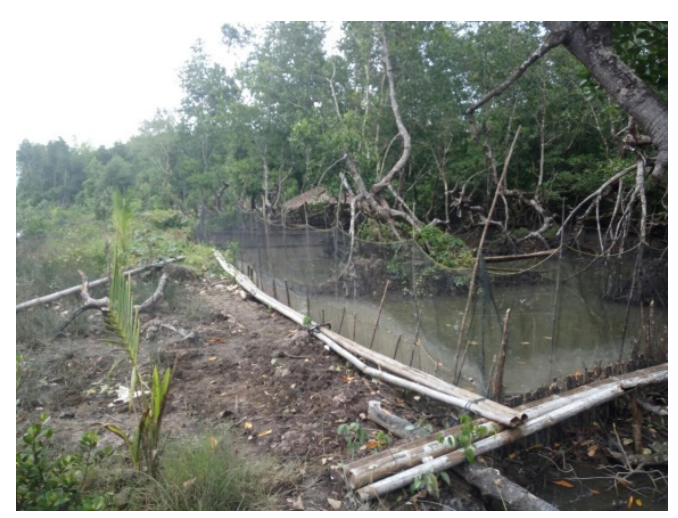

(b)

Gambar 1. (a) dan (b) Kondisi Tambak awal (existing) Milik Pokdakan 


\section{Penyiapan tambak budidaya}

Penyiapan tambak merupakan kegiatan pra budidaya. Hal ini bertujuan agar tambak mampu menjadi habitat yang nyaman bagi komoditi-komoditi yang dibudidayakan. Prasetiyono (2014) menyatakan bahwa penyiapan wadah budidaya merupakan tahapan pra kegiatan budidaya. Kegiatan penyiapan tambak yang dilakukan antara lain: penambahan petak tambak, pendalaman tambak, perbaikan pematang dan pemasangan pintu air untuk menjaga ketersediaan air didalam tambak. Petakan tambak yang baik harus didesain sesuai dengan kondisi dan sifat perairan (sungai) serta ditunjang oleh faktor biologis, fisik, ekonomi, dan sosial (Iskandar, 2002).

Perbaikan tambak dilakukan dengan bantuan alat berat. Setelah tambak diperbaiki, tambak dimasukan air dari aliran anak sungai dan dibiarkan selama dua minggu agar kualitas air lebih stabil. Selanjutnya dilakukan pemasangan pagar yang terbuat dari waring disekeliling tambak. Waring yang digunakan adalah waring hitam sebanyak dua lapie. pematang diperbaiki harus dilakukan pemagaran tanggul. Pemagaran bertujuan agar kepiting bakau tidak melarikan diri dari tambak dan mencegah masuknya predator/ pengganggu dari luar. Pemagaran dapat menggunakan pagar bambu atau waring yang ditempatkan di sekeliling pematang bagian dalam.

Setelah tambak terkondisikan dengan baik, selanjutnya dipasang perangkat yang menjadi kebutuhan untuk kegiatan budidaya. Perangkat-perangkat yang dipasang diantaranya yaitu karamba/kurungan untuk pemeliharaan sebagian kepiting bakau dan keramba waring tancap untuk penampungan sementara benih ikan bandeng. Pemeliharaan sebagian kepiting bakau di karamba/kurungan bertujuan untuk memudahkan sampling dan pengontrolan pertumbuhan kepiting bakau. Pemeliharaan benih ikan bandeng yang berukuran nener atau glondongan bertujuan untuk mempercepat pertumbuhan dan meningkatkan daya hidup ikan bandeng (Tim Perikanan WWF-Indonesia, 2014).

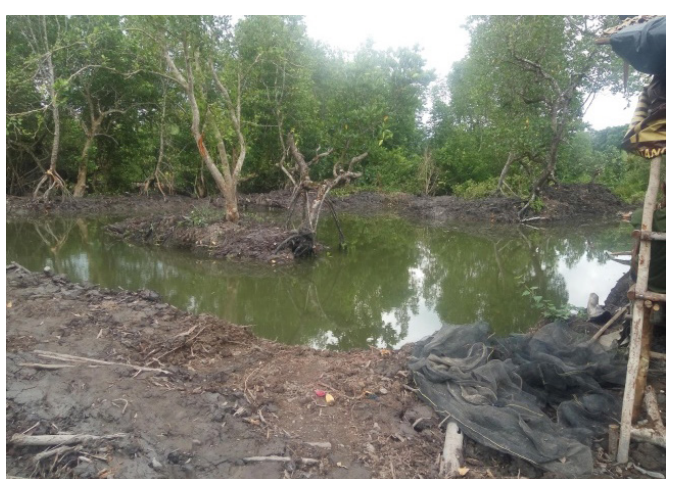

(a)

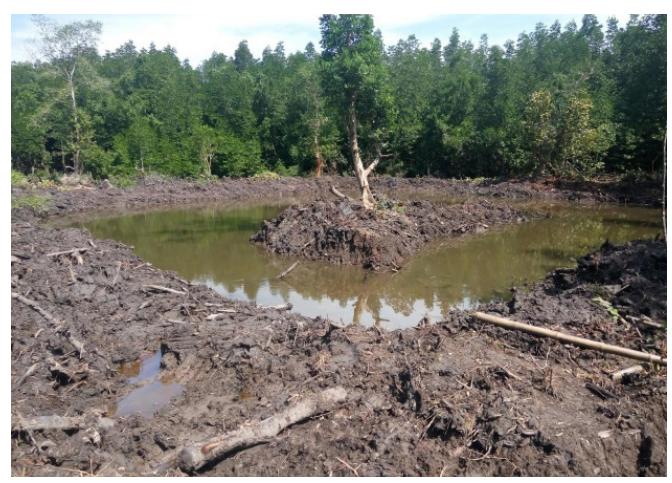

(b)

Gambar 2. (a) dan (b) Tambak Hasil Perbaikan

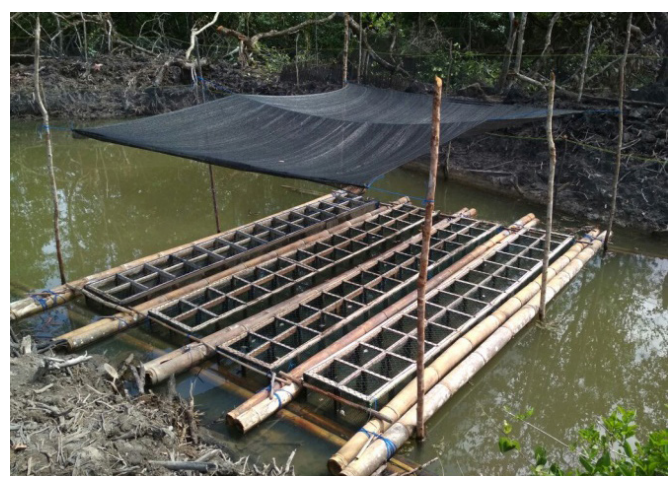

(a)

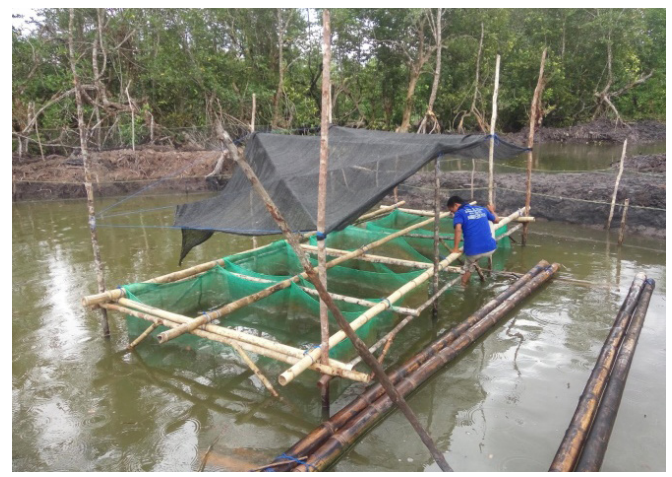

(b)

Gambar 3. (a) Karamba: (b) Keramba waring tancap 


\section{Penebaran Bibit Kepiting Bakau dan Ikan Bandeng}

Bibit kepiting bakau yang ditebar di tambak berasal dari hasil tangkapan nelayan di Sungai Selindung, Kecamatan Merawang, Kabupaten Bangka. Ukuran kepiting bakau yang dijadikan bibit yaitu 100-150 gram. Panjang karapaksnya yaitu 10-12 cm. Bibit kepiting bakau yang digunakan yaitu kepiting bakau yang usianya tidak lebih dari 3 hari setelah ditangkap dari alam. Usia 3 hari adalah usia maksimal kepiting bakau untuk dapat bertahan didarat. Bila lebih dari 3 hari maka kepiting bakau sudah lemah dan tidak optimal untuk dipelihara. Hal ini dikarenakan karakteristik kepiting bakau yang habitat hidupnya yaitu di air payau. Sulistiono et al. (2016) menyatakan bahwa habitat alami kepiting bakau adalah daerah perairan payau yang dasarnya berlumpur dan berada di sepanjang garis pantai yang banyak ditumbuhi pohon bakau (mangrove).

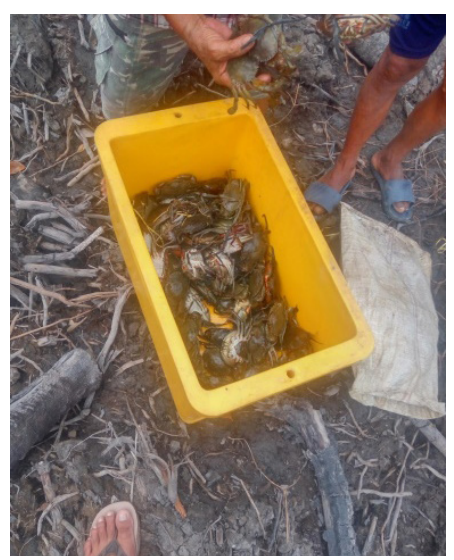

(a)

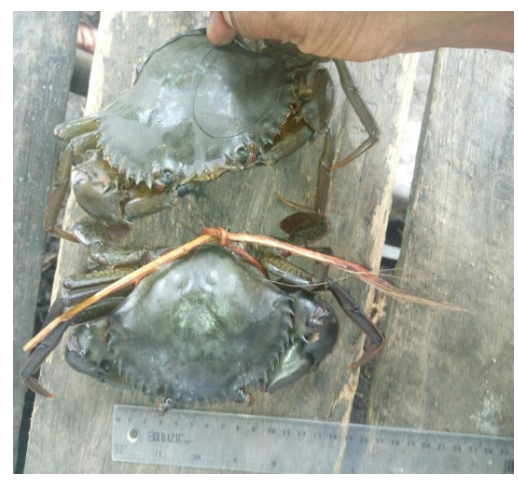

(b)

Gambar 4. (a) dan (b) Kepiting Bakau Yang Digunakan Sebagai Bibit
Benih ikan bandeng yang ditebar adalah benih yang berukuran kecil yaitu sebesar jarum. Benih didapatkan dari luar Pulau Bangka. Hal ini dikarenakan di Bangka Belitung belum ada balai benih ikan atau para pembudidaya ikan yang melakukan kegiatan pembenihan ikan bandeng. Benih yang didatangkan merupakan benih unggul yang dipilih dengan ukuran yang seragam. Pembelian benih yang berukuran sebesar biji jarum dikarenakan untuk meminimalisasi terjadi kematian pada benih. Benih yang sudah berukuran lebih besar bila diangkut pada kepadatan yang tinggi rentan mengalami kematian atau tingkat survival rate nya rendah. Hal ini dikarenakan selama proses pengangkutan akan terjadi gesekan antar ikan sehingga sisik ikan bandeng akan terkelupas. Terkelupasnya sisik ikan bandeng ini akan menyebabkan ikan bandeng menjadi stres dan mengalami kematian. Menurut Johan et al. (2009), benih ikan bandeng lebih baik pengirimannya pada ukuran yang kecil dibandingkan ukuran yang besar. Hal ini bertujuan untuk meminimalisasi tingkat kematian dan memperbanyak jumlah yang dapat dikirim.

Bibit kepiting bakau ditebar pada tambak dan karamba. Penebaran bibit pada tambak dan karamba memiliki kelebihan dan kekurangan. Kelebihan penebaran bibit pada tambak yaitu padat tebarnya lebih tinggi dan pertumbuhannya lebih cepat. Namun kelemahannya yaitu lebih sulit panen dan ukuran kepiting yang ditebar harus seragam. Pemeliharaan kepiting bakau pada karamba memiliki keunggulan, lebih mudah dikontrol pertumbuhannya, lebih terjaga dari predator dan lebih mudah panen. Kekuranggannya yaitu lebih lambat pertumbuhannya dan biaya produksi lebih meningkat. Pemanenan kepiting bakau dilakukan setelah pemeliharaan selama 3 bulan dari ukuran 150 gram. Proses awal penebaran benih ikan bandeng dilakukan pada waring yang ditancapkan didalam tambak. Benih ini tidak langsung dilepas di badan air tambak. Penebaran pada waring ini bertujuan agar benih lebih mudah dikontrol, mudah diberi 
pakan serta tidak mangsa oleh predator yang mungkin terdapat didalam tambak. Penebaran dilakukan pada saat benih yang dikirim dari luar Pulau Bangka tiba di Pulau Bangka. Benih diangkut kemudian tiba dilokasi tambak pada sore hari dan dilangsung ditebar di waring yang sudah disiapkan. Waring yang digunakan untuk penebaran yaitu sebanyak dua waring dengan masing-masing waring berukuran 4 × 5 × 2 meter $^{3}$.

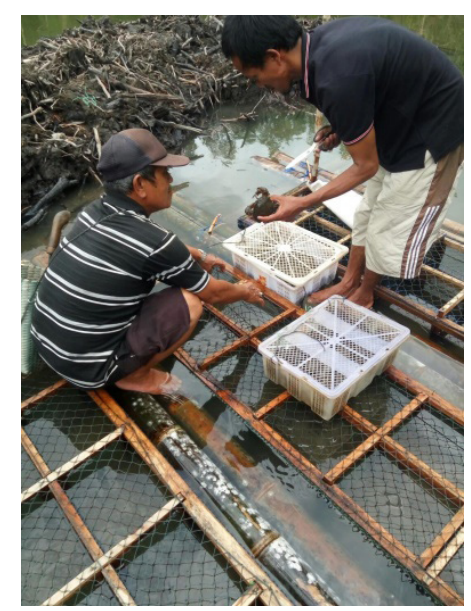

(a)

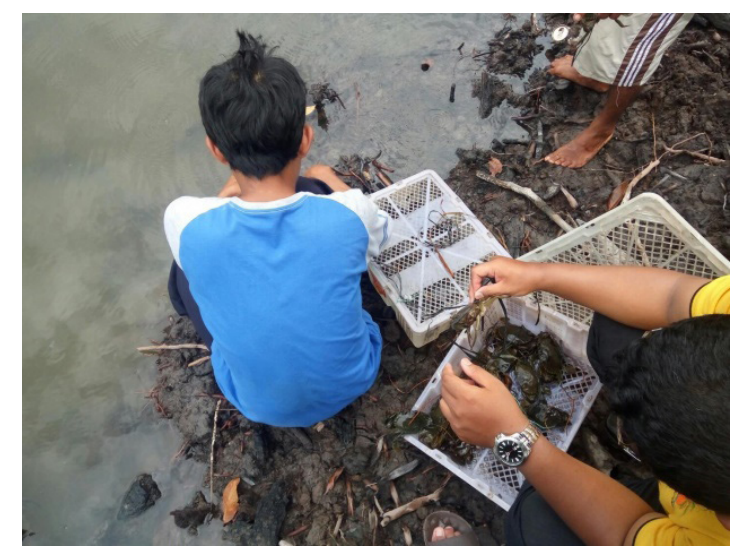

(b)

Gambar 5. Proses Penebaran Kepiting bakau di tambak ; (b) Proses Penebaran kepiting Bakau di Karamba

Selama pemeliharaan pada waring, benih yang berukuran jarum diberi pakan buatan berbentuk tepung halus. Pemberian pakan berupa tepung halus ini menyesuaikan dengan ukuran bukaan mulut dari benih ikan. Setelah benih berukuran lebih besar, benih dipelihara dengan cara diepas dari waring ke tambak. Pemeliharaan langsung di tambak ini karena benih sudah cukup kuat dalam bergerak. Hal ini bertujuan agar benih lebih mudah tumbuh dan besar.

\section{Pemeliharaan Kepiting Bakau dan Ikan Bandeng}

Proses pemeliharaan kepiting bakau dilakukan dengan memberikan pakan berupa ikan rucah segar. Ikan rucah segar yang dipilih karena jika ikan rucah sudah dalam kondisi tidak segar, maka kepiting bakau tidak tertarik untuk mengkonsumsinya. Wedjatmika dan Dharmadi (1994) dalam Natan (2014) menyatakan bahwa ikan rucah yang segar dari segala jenis dapat diberikan pada kepiting bakau. Ikan rucah merupakan ikan-ikan hasil tangkapan nelayan yang tidak dikonsumsi dan tidak memiliki nilai ekonomis. Ikan rucah sebagai pakan pada pemeliharaan kepiting bakau di Pokdakan Perpat Permai cukup mudah dan murah untuk didapatkan. Hal ini dikarenakan daerah Kecamatan Belinyu merupakan daerah yang memiliki laut dan banyak terdapat nelayan yang mendapatkan ikan-ikan rucah. Sebelum diberikan pada kepiting bakau, ikan rucah diperkecil ukurannya dengan cara dipotong-potong terlebih dahulu. Hal ini bertujuan agar kepiting bakau lebih mudah mengkonsumsi ikan rucah tersebut. Pakan diberikan sebanyak dua kali yaitu pada waktu pagi dan sore hari. Persentase ikan rucah yang diberikan yaitu sebanyak $10 \%$ per-hari dari bobot tubuh. Menurut Natan (2014), Pemberian pakan ikan rucah segar yang ideal pada kepiting bakau dilakukan setiap hari dengan perkiraan $10 \%$ dari berat individu. Rangka (2007) menyatakan bahwa kepiting bakau yang diberikan pakau berupa ikan rucah akan memberikan efek menyuburkan air dan menstimulir pertumbuhan plankton akibat dari sebagian sisa pakan/protein yang terlepas berfungsisebagai pupuk. Plankton inilah yang bisa dimanfaatkan oleh bandeng disamping klekap yang ada. 


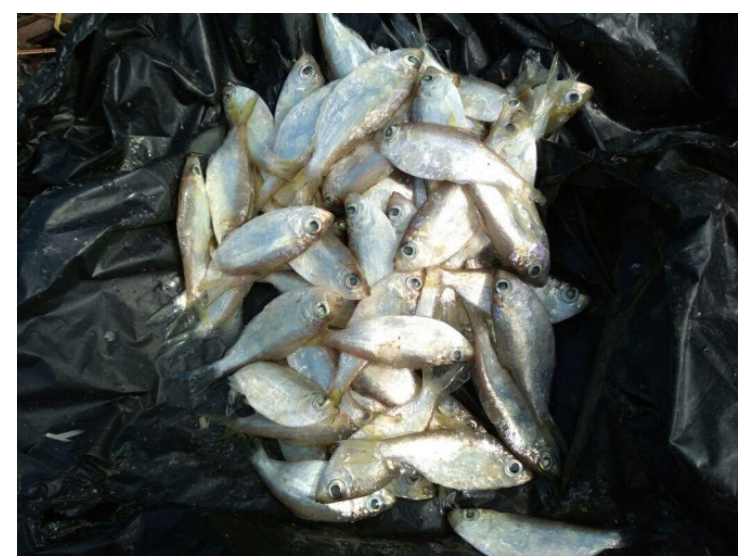

Gambar 6. Ikan rucah Sebagai Pakan Kepiting Bakau

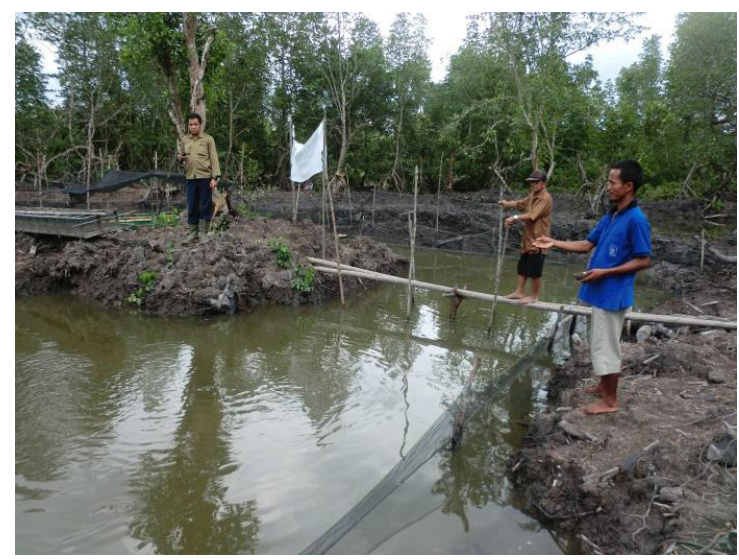

(a)

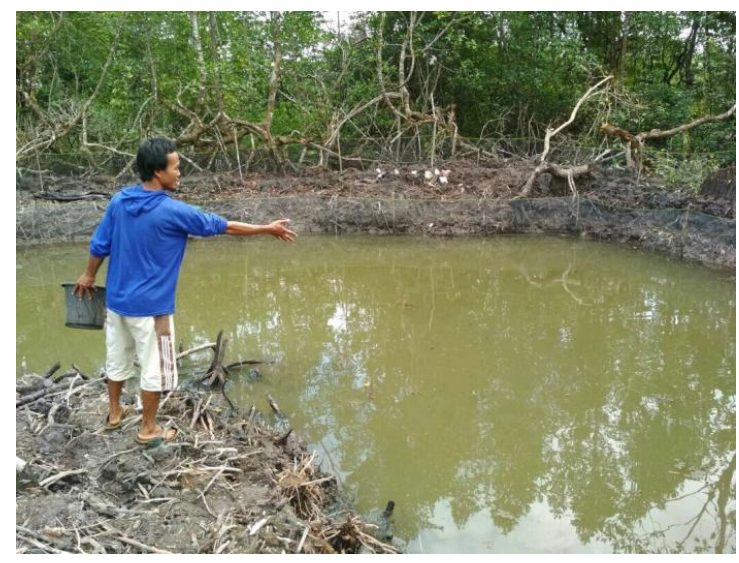

(b)

Gambar 7. (a) Proses Pemberian Pakan Ikan Rucah untuk kepiting bakau; (b) Pemberian Pakan buatan Komersil untuk Ikan Bandeng

Proses pemberian pakan dilakukan setiap hari sampai tercapai ukuran panen. Pemberian pakan dilakukan pada kepiting bakau yang dipelihara di tambak dan karamba. Pemberian pakan bertujuan untuk meningkatkan pertumbuhan sampai ukuran yang diharapkan. Menurut Natan (2014), kondisi pertumbuhan yang terlihat dari pertambahan berat maupun panjang akan terlihat nyata apabila kondisi habitatnya baik dan pakan yang diberikan bernilai gizi yang bagus. Selain itu, kondisi lingkungan yang mendukung serta keadaan geografis yang cocok merupakan areal habitat kepiting bakau. Selama proses pemeliharaan dilakukan sampling dengan menggunakan alat tangkap ancho/pentor untuk melihat proses pertumbuhan dari kepiting bakau yang dipelihara di tambak.

Pada proses pemeliharan ikan bandeng yang seringkali berada pada kondisi cuaca dan lingkungan yang tidak stabil menyebabkan sejumlah benih mengalami kematian. Kematian ini dinilai masih dalam batas kewajaran. Karena jika dibandingkan dengan jumlah yang ditebar presentase kematiannya masih tergolong rendah. Selama pemeliharaan ikan bandeng pada tahap awalnya diberikan pakan berupa pakan buatan pabrik berbentuk tepung halus. Pemberian pakan dilakukan sebanyak tiga kali sehari. Pemberian pakan pada ikan-ikan bandeng yang dipelihara dilakukan sebanyak tiga kali sehari dengan menggunakan pakan buatan. Jumlah pakan yang diberikan sebanyak 3-5\% dari bobot tubuh ikan. Seiring dengan bertambahnya ukuran pemberian pakan pabrik semakin dikurangi karena ikan bandeng sudah mulai bisa mengkonsumsi fitoplankton atau mikroalga dan lumut-lumut yang banyak tumbuh di tambak.

Selama proses pemelharaan terlihat ikan bandeng cukup aktif dalam bergerak dan ketika diberi makan juga terlihat pergerakannya. Pertumbuhan ikan bandeng selama pemeliharaan terlihat cukup baik. Pertumbuhan ikan oleh beberapa faktor, diantaranya yaitu jumlah pakan dan kemampuan ikan dalam memanfaatkan pakan. Feeding frequency dan feeding rate pada pemeliharaan ikan bandeng harus sesuai dengan kebutuhan ikan. Selain itu, kepadatan ikan juga tidak boleh terlalu tinggi karena akan menyebabkan persaingan ikan 
dalam memanfaatkan pakan, sehingga ikan tidak dapat memanfaatkan pakan dengan maksimal. Sabariah dan Sunarto (2009) menyatakan bahwa kecepatan pertumbuhan tergantung pada banyaknya jumlah pakan yang dikonsumsi, jumlah kandungan protein yang terkandung dalam pakan, kualitas air dan faktor internal yang terdapat pada ikan dinataranya yaitu keturunan, umur dan daya tahan serta kemampuan ikan tersebut memanfaatkan pakan.

Selama proses pemeliharaan dilakukan kegiatan sampling terhadap kepiting bakau dan ikan-ikan bandeng yang dipelihara. Hal ini bertujuan untuk memantau perkembangan pertumbuhan dari kepiting bakau dan ikanikan tersebut. Sampling kepiting bakau dilakukan dengan menggunakan ancho. Sedangkan pada ikan bandeng dengan cara ditangkap menggunakan pancing. Secara umum, kepiting bakau dan ikan-ikan yang dipelihara tumbuh dengan optimal. Hal ini terlihat dari ukuran kepiting bakau dan ikan bandeng yang mengalami pertambahan panjang dan berat yang cukup signifikan.

\section{Pemanenan Kepiting Bakau}

Tingginya permintaan dan harga kepiting bakau yang bukan cangkang lunak menyebabkan para pembudidaya melakukan panen kepiting bakau yang belum berwujud cangkang lunak. Proses pemanenan dilakukan secara parsial pada kepiting bakau yang berukuran $1 \mathrm{~kg} / 3-4$ ekor (kurang lebih beratnya $200 \mathrm{~kg}-250 \mathrm{~kg}$ ). Harga jual kepiting bakau ukuran tersebut yaitu Rp 80.000,. Harga ini memberikan keuntungan yang cukup tinggi. Harga beli bibit kepiting bakau yaitu Rp 45.000/9-10 ekor. Pemeliharaan sampai panen memerlukan waktu 3-4 bulan. Kanna (2002) menyatakan bahwa kepiting bakau yang memenuhi syarat untuk dijual terutama untuk memenuhi pangsa ekspor yaitu kepiting bakau yang memiliki berat rata-rata $200-250 \mathrm{~kg}$ atau 4- 5 ekor kepiting yang diikat dengan menggunakan tali. Kepiting bakau yang belum mencapai berat jual tersebut dikembalikan ke tambak pemeliharaan untuk dibesarkan kembali.

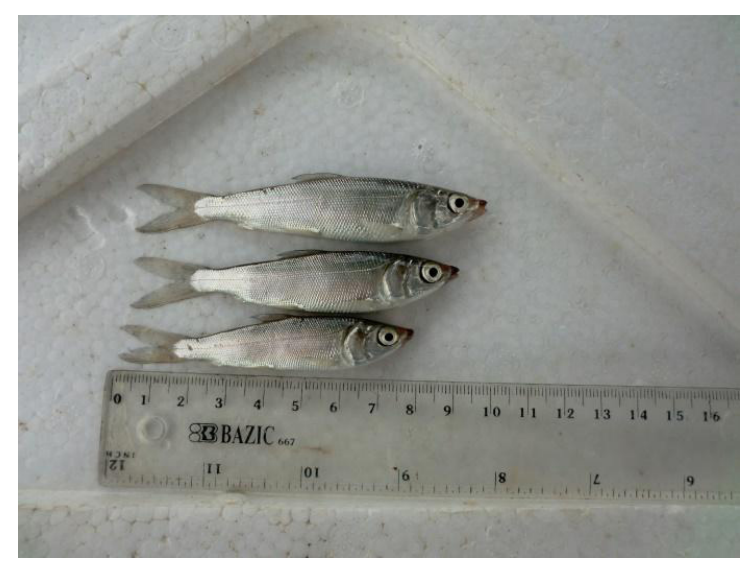

(a)

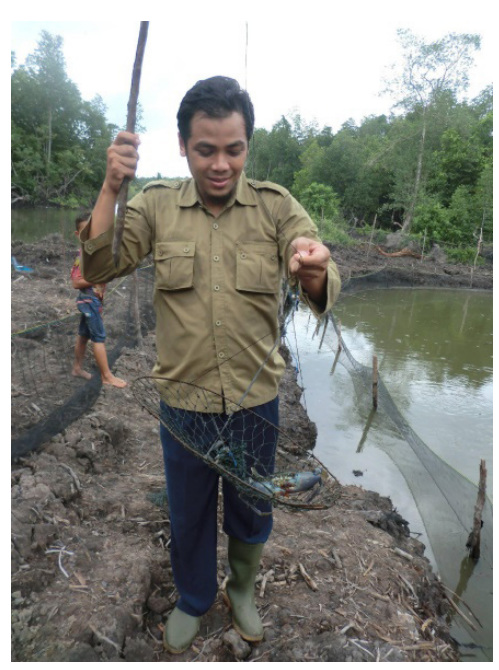

(b)

Gambar 8. (a)Pengukuran sampel Ikan Bandeng;

(b)Pengambilan Sampel Kepiting Bakau, dan

Panen dilakukan secara parsial karena tidak semua kepiting bakau panen dengan ukuran yang sama. Panen parsial juga dilakukan agar siklus atau kontinyuitas kepiting bakau di tambak tetap terjaga. Panen di tahap-tahap pemeliharaan awal dilakukan pada kepiting bakau yang ditebar didalam tambak. Cara melakukan pemanenan dengan menangkap kepiting-kepiting bakau yang ditebar di dalam tambak dengan menggunakan ancho. Pagi sebelum panen dilakukan, kepiting bakau tidak diberikan pakan agar ikan tertarik makan pakan ikan yang diletakan pada ancho.

Hasil panen kepiting bakau dibeli oleh para pembeli yang datang langsung ke tambak dan dijual dipasar lokal yang ada di Kecamatan Belinyu, Kabupaten 
Bangka. Setiap kali kepiting bakau dipanen, hasil panennya selalu terjual. Minat masyarakat yang tinggi terhadap kepiting bakau dan keberadaan kepiting bakau yang sulit didapatkan menyebabkan kepiting bakau selalu dicari oleh masyarakat untuk dikonsumsi. Sebenarnya pasar kepiting bakau didaerah Bangka Belitung maupun luar Bangka Belitung sangat tinggi.

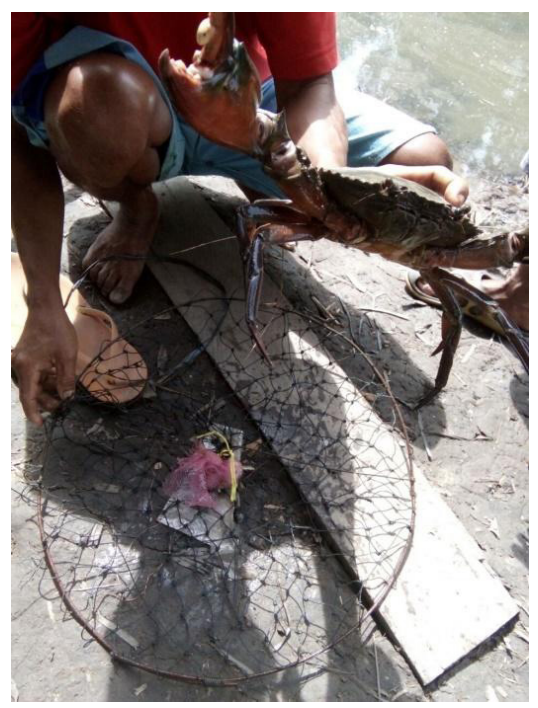

(a)

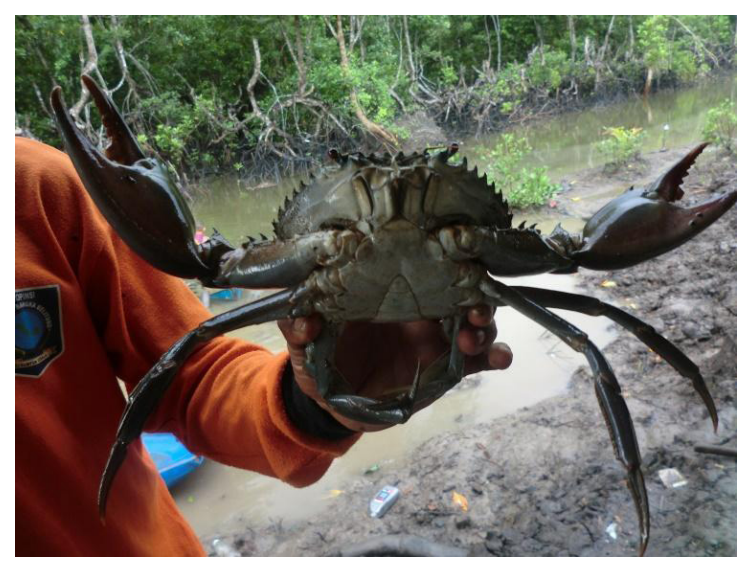

(b)

Gambar 9. (a)Panen Kepiting Bakau dengan menggunakan ancho; (b)Hasil Panen Kepiting Bakau

\section{Kondisi Lingkungan Selama Proses Pemeliharaan}

Selama proses pemeliharaan ikan bandeng, dilakukan proses pemantauan terhadap kondisi kualitas lingkungan. Nilai rata-rata salinitas yang diukur pada tambak kelompok pembudidaya ikan yaitu 24 30 ppt. Nilai ini merupakan kisaran nilai yang sesuai dengan habitat hidup kepiting bakau dan ikan bandeng. Karena kepiting bakau dan ikan bandeng merupakan komoditas yang hidup di perairan payau. Syahid et.al (2006) menyatakan bahwa kisaran salinitas yang optimal untuk budidaya ikan bandeng yaitu 15-35 ppt. Pada kepiting bakau, salinitas optimal untuk pertumbuhannya yaitu $10-30$ ppt (FAO, 2011).

Ikan Bandeng merupakan jenis ikan yang dapat dibudidayakan pada tingkat kepadatan yang tinggi, bersifat tidak kanibal, responsif terhadap pakan yang diberikan, cepat tumbuh dan tahan terhadap perubahan suhu dan salinitas yang ekstrim (Reksono et.al 2015). Salinitas juga merupakan salah satu faktor pembatas pada metabolisme kepiting bakau karena salinitas mempengaruhi molalitas cairan di dalam tubuhnya (Villareal et al., 2003). Kondisi seperti ini akan mempengaruhi proses fisiologis yang berdampak pada kelangsungan hidup kepiting bakau.

Nilai $\mathrm{pH}$ pada tambak yang terukur selama kegiatan yaitu $6,8-7$. Nilai ini merupakan nilai yang sesuai dan layak dengan kehidupan ikan bandeng dan kepiting bakau. Menurut Suparjo (2008), nilai pH air dengan kisaran 6,9-7,1 merupakan nilai $\mathrm{pH}$ yang mendukung kegiatan budidaya ikan Bandeng. Berdasarkan FAO (2011), nilai pH yang optimal untuk pemeliharaan kepiting bakau yaitu $7-8,5$. Pada air yang memiliki kandungan $\mathrm{pH}$ yang sangat rendah (dibawah 5), air tidak dapat digunakan untuk proses budidaya ikan karena ikan akan terhambat pertumbuhannya dan mengalami kematian (Lekang 2007). Pada air yang memiliki kandungan $\mathrm{pH}$ rendah, ikan akan mengalami kerusakan pada insang, kulit dan mata (Lekang 2007). pH rendah menyebabkan lendir pada insang akan sangat tebal sehingga ikan mengalami kematian. 


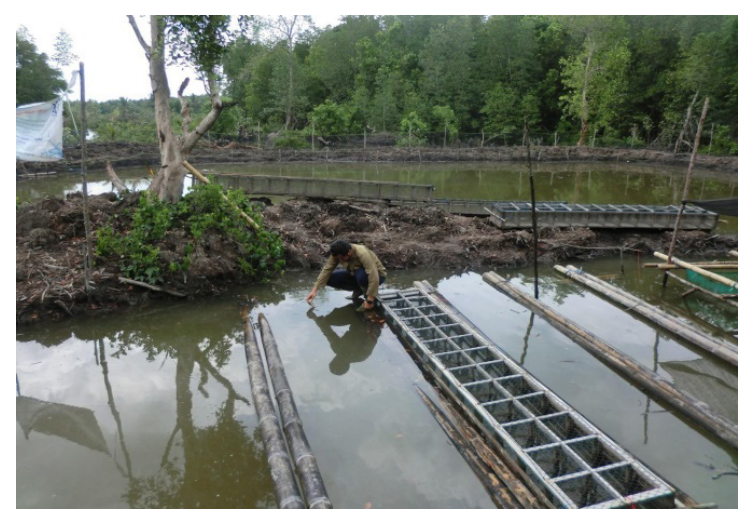

Gambar 10. Proses Pengukuran Kualitas Air Insitu

\section{Dampak Teknologi terhadap Kegiatan Budidaya Ikan Mitra}

Dampak signifikan dari penerapan teknologi polikultur kepiting bakau dengan ikan bandeng ini yaitu berjalan optimalnya kegiatan produksi pada tambak-tambak yang dimiliki oleh para pembudidaya. Kondisi ini berdampakpositif pada meningkatnya keuntungan yang didapatkan oleh para pembudidaya ikan. Mitra pembudidaya dapat memanen komoditi hasil budidaya dengan jenis yang lebih banyak yaitu kepitig bakau dan ikan bandeng sehingga keuntungan yang didapatkn lebih optimal. Jika selama ini kegiatan produksi stagnan dan tidak berjalan dengan baik, maka teknologi polikultur yang diterapkan dapat menghidupkan kegiatan produksi sekaligus menghidupkan kegiatan di kelompok pembudidaya ikan. Aktivitas para pembudidaya ikan lebih produktif, semangat dan berkelanjutan dalam menghasilkan keuntungan usaha.

\section{PENUTUP}

Aplikasi dan desain teknologi efektif dalam kegiatan polikultur kepiting bakau dan ikan bandeng. Proses budidaya yang dilakukan berjalan dengan efesien disebabkan karena dukungan pemberian pakan yang sesuai dan cukup baik nutrisi maupun kuantitas dan didukung oleh kondisi lingkungan yang terjaga. Teknologi yang diterapkan berjalan dengan baik dan membantu mitra pembudidaya dalam menjalankan kegiatan produksi kepiting bakau dan ikan bandeng dalam satu tambak secara efesien. Hasil panen yang didapatkan mampu memberikan keuntungan yang optimal bagi para pembudidaya.

Teknologi budidaya kepiting bakau dengan sistem lepas tambak dan karamba yang dipolikultur dengan ikan bandeng dapat didesiminasikan kepada para pembudidaya ikan lainnya yang ada di Bangka Belitung karena lebih efisien dalam kegiatan budidaya

\section{UCAPAN TERIMA KASIH}

Terima kasih disampaikan kepada Direktorat Jenderal Pendidikan Tinggi (DIKTI) atas pendanaan kegiatan dalam skema pendahaan Hibah Ipteks Bagi Masyarakat tahun 2017.

\section{DAFTAR PUSTAKA}

Effendi I. 2004. Pengantar Akuakultur. Jakarta : penebar Swadaya

(FAO] Food and Agriculture Organization. 2011. The State of Word Fisheries and Aquaculture. Rome: FAO.

Ghufran, MHKK. 2009. Budidaya Perairan Buku Kedua. Penerbit PT. Citra Aditya Bakti

Hafiludin. 2015. Analisis Kandungan Gizi Pada Ikan Bandeng Yang Berasal Dari Habitat Yang Berbeda. Jurnal Kelautan Volume 8 No.1: 37 - 43.

Iskandar Kana, 2002. Budidaya Kepiting Bakau. Cetakan ke-5. Yogyakarta: Penerbit Kanisius.

Johan O, Sudrajat A, Hadie W. 2009. Perkembangan Perikanan Ikan Bandeng Pada Keramba Jaring Tancap di Pandeglang, Provinsi Banten. Media Akuakultur Volume 4 No. 1. 40-44. 
Kanna I. 2002. Budi Daya Kepiting Bakau, Pembenihan dan Pembesaran. Jakarta : Kanisius.

Lekang OI. 2007. Aquaculture Engineering. UK: Blackwell Publishing.

Midlen A,Redding TA. 1998. Environmental management for Aquaculture. USA : Springer.

Muntalim dan Mas'ud F. 2014. Pengembangan Budidaya Dan Teknologi Pengolahan Ikan Bandeng (Chanos - Chanos Forsskal) Di Kabupaten Lamongan Guna Meningkatkan Nilai Tambah. Jurnal Eksakta (2) : 1. 54-65.

Moosa MK, Aswandi I, Kasry A. 1985. Kepiting bakau, Scylla serrata (Forskal, 1775) dari perairan Indonesia. Jakarta (ID): Lembaga Ilmu Pengetahuan Indonesia

Natan Y. 2014. Penggemukan Kepiting Bakau Scylla Serrata Berukuran Kecil Hasil Tangkapan Nelayan Di Dusun Wael, Kecamatan Piru, Kabupaten Seram Bagian Barat. Jurnal Perikanan (J. Fish. Sci.) XV (2): 79-87

Prasetiyono, E. 2013. Efektivitas Kompos Batang Pisang (Musa sp.) Untuk meminimalisasi kandungan logam berat timah hitam $(\mathrm{Pb})$ dan menaikan $\mathrm{pH}$ rendah pada media budidaya ikan lele dumbo (Clarias gariepinus). Akuatik-Jurnal sumberdaya Perairan vol. 7 No. 1 : $1-8$.

Prasetiyono E. 2014. Akuakultur Berbasis Kolong Pasca Tambang Timah : Prinsip Pemanfaatan dan Kelayakan Budidaya Ikan. Bulletin Forum DAS, Vol.2 / No.1. Bangka Belitung : Forum DAS.

Rangka, NA. 2007. Status Usaha Kepiting Bakau Ditinjau dari Aspek Peluang dan Prospeknya. Neptunus, Vol. 14, No. 1 : $90-100$.

Rattanachote, A. and Dangwatanakul, R. 1991. Mud crab (Scylla seratta) fattenning in SuratThani Province. The Surat Thani coastal aquaculture development centre, Kanchanadict. Surat Thani Province. Thailand.

Reksono B, Hamdani H, Yuniarti MS. 2012. Pengaruh Padat Penebaran Gracilaria sp. Terhadap Pertumbuhan dan kelangsungan Hidup Ikan Bandeng pada Budidaya Sistem Polikultur. Jurnal Perikanan dan kelautan, 3(3): 41-49.

Suparjo MN. 2008. Daya Dukung Lingkungan Perairan Tambak Desa Mororejo Kabupaten Kendal. Jurnal Saintek Perikanan 4 (1): 50-55.

Sulistiono et al. 2016. Pedoman Pemeriksaan/Identifikasi Jenis Ikan Dilarang Terbatas (Kepiting Bakau/Scylla spp.). Jakarta: Pusat Karantina dan Keamanan Hayati Ikan Badan Karantina Ikan, Pengendalian Mutu dan Keamanan Hasil Perikanan Kementerian Kelautan dan Perikanan.

Syahid M, A. Subhan dan R. Armando. 2006. Budidaya Bandeng Organik Secara Polikultur. Penebar Swadaya. Jakarta. $64 \mathrm{hlm}$

Tim Perikanan WWF-Indonesia. 2014. Budidaya Ikan Bandeng (Chanos Chanos) Pada Tambak Ramah Lingkungan. Jakarta: WWF-Indonesia

Villarreal, H., A. Hernandez-Llamas and R. Hewitt. 2003. Effect of salinity, survival and oxygen consumption of juvenil brown shrimp, Farfantepenaeus californiensis (Holmes). Aqua. Res., 34: 187-193. 